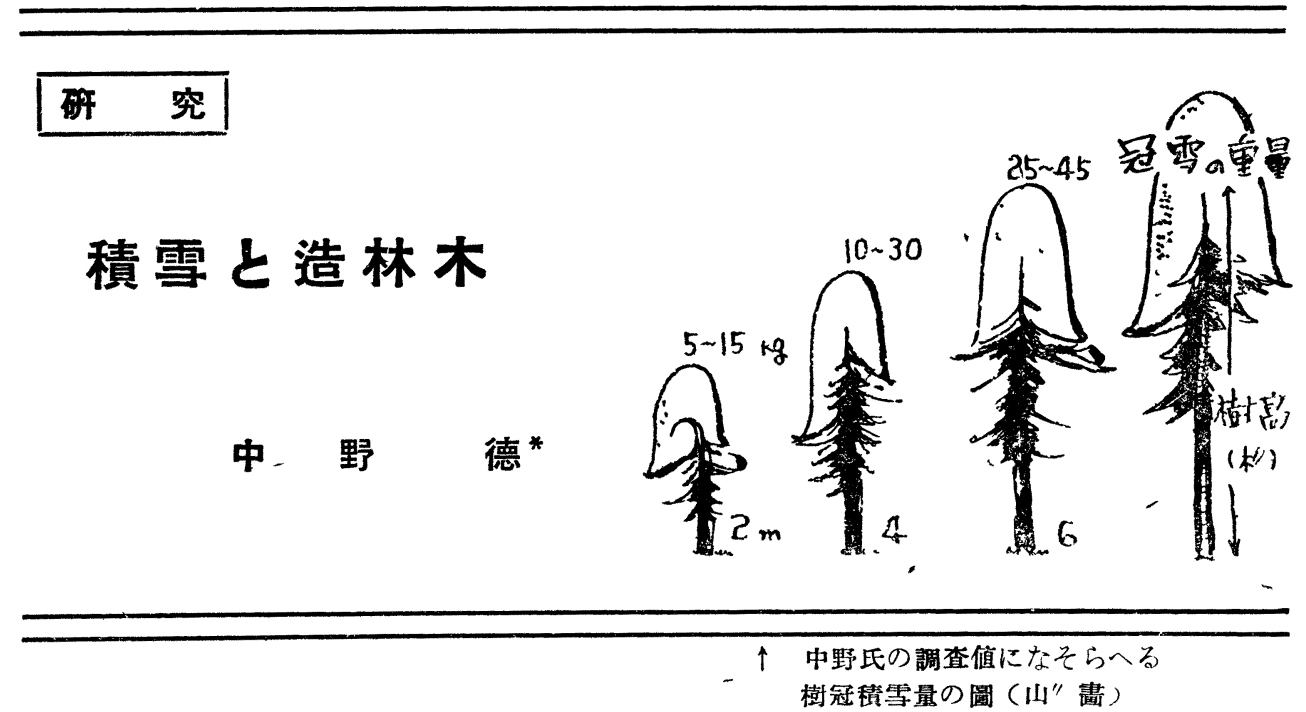

\section{緒言}

北陸の每岸や平野地方には大きた造林地は少く，邓 概六寡雪て爆雪か降つても融け易い。奧地や山岳地方 は主に雜木林地て，山の樹木は梁雪に馱れて・るて雪に 對しては丈夫に䏍つてるる。積雪は每年 5一6m に達 す公地方与あるか，一般に氯罝加低く雪は乾いた輕い 雪てある。從つて兩地方共に大雪の年にも造林木や竹 林なとに雪害を蒙ることは少い。兩地の中間に位する 地方は造林地が多く、積至は每年 1一3m の問にあり盈

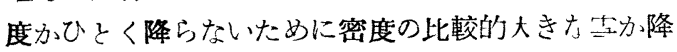
る。殊に不連續線によつて南又は東南方から中共山胍 を越えて暖氣流力日本海から押し出した基氛流の上に のし上つてきた時に降つてくる雪は，漆閏て降り方も 强く雪片も大きく降雪量も多く僅かの間に數十 $\mathrm{cm}$ 栍 ること注珍らしくない。斯る時には交通機關力，不通と なり電燈湶, 電話線なと力切斷され, 山の被害力相當 に多く數十年生の赤松, 杉, 檜, 其他の樹木力篦曲, 傾科，倒伏，割裂，幹折，枝折なと大小の雪害を蒙る こと加屡々ある。然るに元來交通機關や通信機關又は 人畜，住家なとの雪害に對しては，事の大小に係らす 報導せらるつと共に關心を持たれて對策を研究せられ てきたか，山の樹木に對する雪害は直接衣会住に關係
せぬためか；相當大きな被害かあつても忘れられた感 じかあつた。

元林業試驗場勝山森林治水試驗地(福井縣大野郡勝 山町所在)は丁度か、る雪害の多、平地と山岳地との

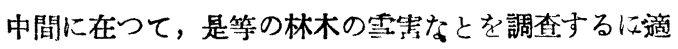
富寺場所てある。筆者は同試驗地へ勤務中機會ある每 に樹冠積雪量, 造林木の雪里, 造休地の積胥, 階段造 林, 階段地の積雪なとに就て觀察し又則定し調查研究 してきた。中途て轉勤して充分な資料を得るに到らな かつ大か：こ、に蒐集し得た乏しい資料に上りその愖

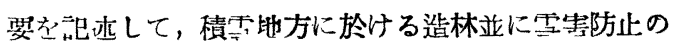
參考心供する次第てある。份本調查や則定に當り，深 呈中に御苦筞を湞はした助手菅原泰作君, 桶野政男 君，に對して梁甚の謝意を表するものである。

\section{1 樹 冠の積雪}

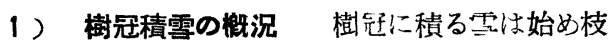
葉に落下した雪片か附着と同時に多少融解して原形を 變するものてあるか, 次第に落ち种なるに從つて死の 粘性により融着增大し原形のまう積る樣になる。降り 始めの頃は粉雪, 灰雪, 又は綿雪なとふわふわとした 密度 0.05-0.07 の小さな輕、狀態に在り, 僅かの風

\title{
* 林業試驗場大正試驗地
}


や小さな外力によつて子容易に飛散し，又は枝梢自體 の彈力による僅かの動摇にも容易に自然落下寸る。雪 の止んた後林內を步人と樹上の積雪が雪煙をたてっ一 時に落下寸る光景に遭遇することか心る。是等樹昝の

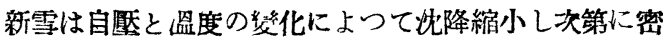
度加增大寸る。

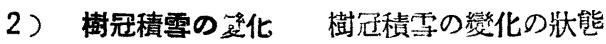
を觀察するに，氣盈か $0^{\circ} \mathrm{C}$ 以下の間は融解現象は起ら ないが，字面蒸發と自厎のため僅かに容積は減する。

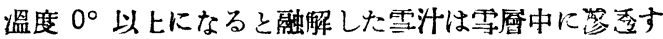
る。雪冠が厚く內部の溫度が非常に低温な時水认凍結 するが，北阷地方の平地ては多くの場合雪粒間の小隐 を通つて泿閏し雪賀を头第に變化させる。此の間樹冠 積雪の體積は减するか重量は差程變らない。更に融解 が續くと雪けは冠雪の下底,樹葉,樹幹を傳つて商下寸 る。斯樣な壯態か續ナは始めふわふわしてわた新雪は 餅雪となり，閏雪，水雪となつて雪粒は次第に粘性を 失ひ，逐に粗目雪々なつて風などの僅かな外力，又は 幹や枝の反撥力に上万動摇のため容易に落雪与るに到 る。樹上の雪正か落七ない以前に氯溫加 $0^{\circ}$ 以下に降 下寸ると融解現解は衰へ，滴下してみた雪汁は葉や枝 に徐々に凍着して一部は樹水狀文は氷柱狀となる。雪 面什近は氷板壯となり內部の雪什も凍結を起し，弱い 風や枝幹を動摇した位では落下しなくなる。更に此の 上に新雪か降り積ると雪过は增大して重くなり，枝葉 は一層更れ下り幹は次第に彎曲の度を堆し，逐に荷重 が或る限度に達すれは折れるか，裂るか，又は倒れる かするのてある。

3) 雪 玉 杉や懀の樣几樹冠か圓雓狀をな 寸木には㱠と見られないが，澍迋の上部が稍本かな松 や枝の股力掐神型になつて友る樹上に於て，他の部分 の等は融解し去り 刃は地上に落下し た後に，大雪塊力。 殘るのを見かける ことかありこれ を雪玉叉は鲁手軧 と稱してる分。雪 玉は初めのらちは 一般の樹冠積雪と 變らないか，次第
に締雪となり更に白壓及雪面附近の融解雪计が內部に 透するに從つて外部から粗目雪に變り, それが塞氣 に遇つて凍轺し雪水狀となつたものてもる。形は上部 は大體乎球形であるが下部代凹凸ある不整形で,'枝や 幹葉に谏着して容易に落ちない。內棓の密度は相當大 きく融け方子晚く新雪力降万と墫大寸る。雪玉を縱に 切り割つて見ると第 1 圆の如く降雪回數を示す周邊つ 稍下つた縞が瑪埌の玉の樣に見られる。

4) 樹冠皘雪量 樹冠に積つた雪の㫣を則方 ことは非常に困難てあるか，新雪力゙降つた直後に数回 に亘つて6 i 生から 35 年生位まての杉, 檜, 赤松など 36本に就て樹冠に樍つた雪を落してその重量を測つて 見た。測り方は先つ尌下の雪債をカンデキて静かに踏 み固めてから，莫䒴数枚を嘹間なく敷き並へて樹上の 哥をコンキや笔て吒き落して寄世集めその全雨量を睤 つたのてあるか，幹や吱葉に附着して摇り動かしても 㖿いても落ちない雪に就ては，2，3の枝を伐り取つ て附着してるる雪を乾も，その前後の重さの差を゙以 て, 樹木全體に附着し殘つ大雪の量を推則し，寄世集 めて測つた雨量に加算した。結果は第1 表の如くであ る。

第1回昭和 17 年1月15日に則つたものは，小 さな杉であつて，樹冠には 9-11 kg の積雪か女り之 を樹冠投影 $1 \mathrm{~m}^{2}$ 當りに換算すると平均約 $10 \mathrm{~kg}$ 子な り，此の時平地積つた新雪 $20 \mathrm{~cm}$ の重量 $1 \mathrm{~cm}^{2}$ 當り $23.75 \mathrm{~kg}$ に比皎するとその 35 -49\% か各の樹冠に積 つた計算になる。

第 2 回全年 1 月 16 日に測つたものは杉の樹 冠に積つた雪の量て全量は $22-33 \mathrm{~kg}$ 出り, 樹冠の多 くは雪の荷重のため值立し得す既に相當の彎曲をな し，甚しいものは先端部が地上の雪面に届いてみた。 此の時林外平地の積雪量は $75.5 \mathrm{~cm}$ あつた方前日來の 新雪は $30 \mathrm{~cm}$ てあつて,この $1 \mathrm{~m}^{2}$ 當りの新雪の車さ $33.9 \mathrm{~kg}$ に比較すると當日の樹冠積雪量は 23 - $48 \%$ と なり本均 $40 \%$ ですう。

第3 回 2 月 12 日, 當日は早く風加出て樹上の雪 積が落ちたのて，僅かに杉 2 本と赤松 2 本を則定し得 たに過きなかつたか，第一の杉は先端か積雪面に接す

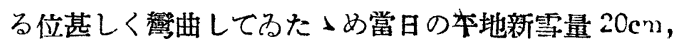
$15 \mathrm{~kg}$ に比較すると $70 \%$ か樹に積つたことになるか， 此の中には多少當日以㷙の雪も加はつてるた樣てあ 


\section{(62)}

る。第2の杉は僅かに曲つてるたカ平地の新雪に對し て $24 \%$ 强が啧つた計算になる。赤松の第 1 は枝の數 が少かつた めに $14 \%$ ，第 2 の赤松は樹冠面㧼は小 さからたが枝數む多く某も密に着いてるた〉めに積雪 㢆は割合に多く $24 \%$ が㨽上に榬つてるた。

第4回 2 月 13 日は主に $7 \sim 15$ 年生の杉に就て 測定し, 本地の新積雪量は $48 \mathrm{~cm}$ て， $1 \mathrm{~m}^{2}$ 當りの重 量は $40.3 \mathrm{~kg}$ であるが，之に對して樹上に積つた雪の 量は 13-63\% の間にあり, 各の木に皘つた割合は大 きかつたが，その本均は $26.6 \%$ てあつた。又 35 年 生の杉は 36\% の雪か積つでた。

第 5 回 昭和 18 年 2 月 9 日新雪 $24 \mathrm{~cm}$ 力樹冠に樻つ た量を則つた。當日午前中は氣溫は概小放に降つて

風速も $0.5 \mathrm{~m} / \mathrm{s}$ 以下であつたつめに測定中に樹冠 よりの落雪や融雪は殆と起らなかつたが, 林外積雪の 深さは 147cm もあつた。12 年生から 21 年生まての 杉に就て則つた結果は林外の新雪積量 $1 \mathrm{~m}^{2}$ 當り $24.17 \mathrm{~kg}$ に對して 23-71\%の間にあり，本均 $34.3 \%$ て，稖雪前の樹冠投影面積に對しては 17-41\% の間 にあり本均 $28.9 \%$ でつた。佮當日測つた杉の中で 一番小出、12 年生, 直徑 $5 \mathrm{~cm}$, 樹高 $4.5 \mathrm{~m}$ のものは 箖雪荷雭のため特に枝か垂れ下つてるてその投影面積 上の䖽雪割合は $71 \%$ 多あつたか，その他の樹冠積雪 量は平均 $28 \%$ で積雪前の投影面積に比して僅に少い 程度ですった。當日測つた檜は杉より 5\% 以上少 なく, 樹佘表面積に付ての割合は非常に少なく平地積 雪の 6.3-19.8\% で平均 10.5\% に過ぎかつた。

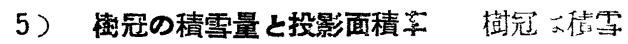

の增加に件ひ次第に枝を垂れその投影面倩を淑少する

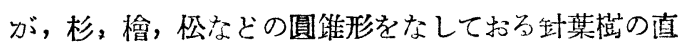
立木で積雪前の凡そ $75 \%$ 程度となる。樹冠心留つ た雪の量やその密度に依つて多少の相違はあるか，筆 者か則つた樹冠の中て最も投影面積の小さくなつたも のは 47\% てあつた。大體に於て 60\% 以下になれは 枝础は非常に急に垂れ下り，瀑雪は勿論輕い粉等や灰 雪ても自然に落下寸ることか多い。又一般には新積雪 わ $30 \mathrm{~cm}$ 以上に達した場合, 又風力゙出て幹や枝を摇り 動かした場合，枝自體の彈力によつて撥ね返つた場合 には䖽雪の一部は落雪して元の形に戻らんとするすの で從つて 60\% 以下に減ずることは稀てある。一度瀜 けた雪が急に溫度の降下にあって枝葉に凍着した上に

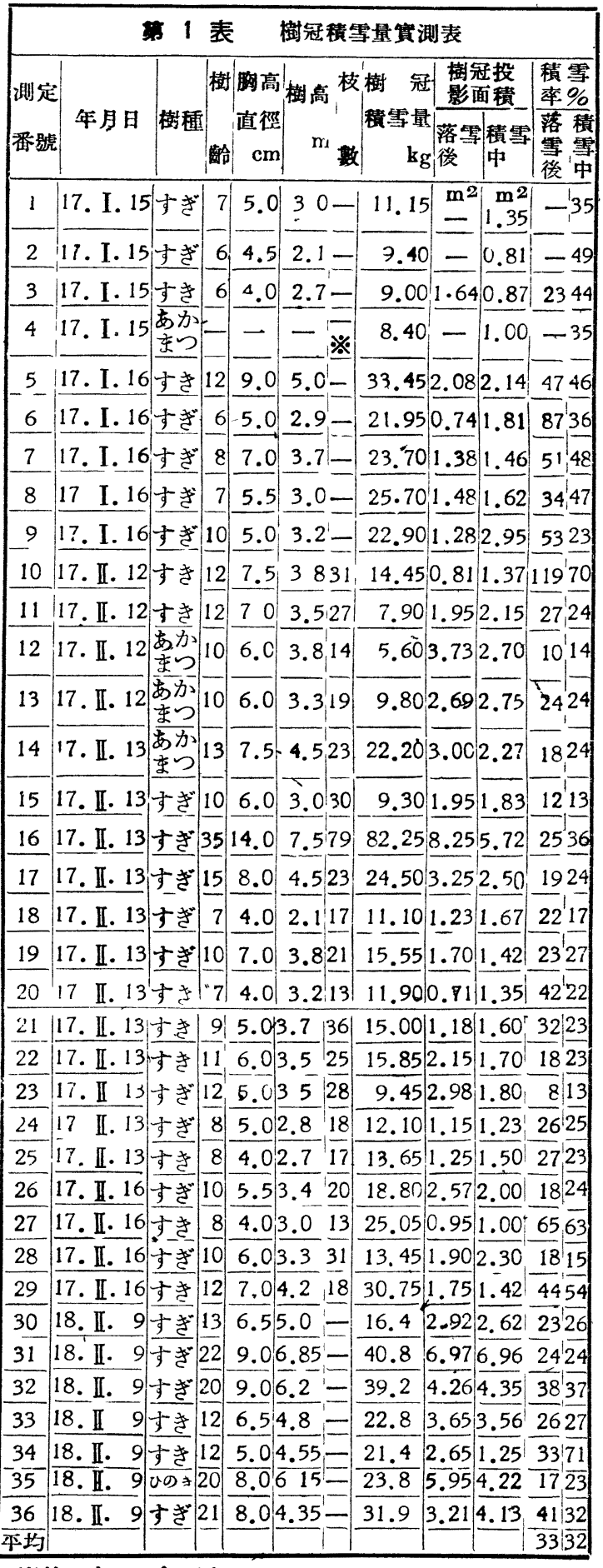

※枝一本につき測定 
更に滀つた粘性の新雪が積つた時には $60 \%$ 以下に枝 か垂れ下り，樹冠の積雪も容易に落雪せ始ことがあ

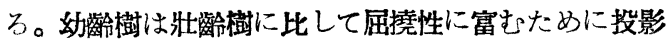
面積率は減少するものてあるか，又彎曲して牛圓形と なり却つて檑加して積雪前の 2.5 倍に達するものも女 る。筆者が測定したもの〉中ては第 3 表の No. 2 の 25 倍弱 No. 5 の 2.3 倍か大きなものてあつた。之 等の樹冠皘雪量は林外新積雪に對して $87 \%$ に及ひ， 逐には雪面に接し更に積雪力檑せば雪中に埋没するも のである。

形の上から樹冠投影型を區別すれは，大體恃老稫木 て直俓の割合に薣高低く枝張りの均勢がとれて居る針 葉樹は第 2 圖，No. 3，No. 3，4 の如き縮小型とな り，幼渷命木は No. 5, №. 8 の如く多くは三角型又は

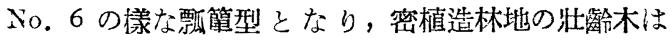
No 29，No 31 の如き變位型となる。斜線は樹冠不責

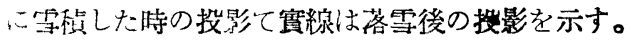

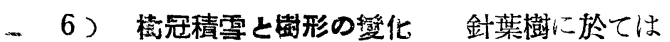
笋が降り續いて樹㓂に積つてくると枝葉は雪の荷雷に 從つて垂礼下り，絞な圓维形は次第に周邊の急な㿣彈 形々なり，樹幹を中心とする投影面倩は凡そ $70 \%$ 位 まで縮小される。前年に伸長した先端剀は木質力柔軟 たために先つ始引に曲つてくる。幼莢令木に比較すると

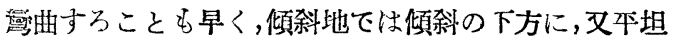
地ては雪の降つてくる方向と反對の方向に又は枝付の 多い方に，林緣ては多く外部に向つて主幹全體力灣曲 し始める。壯雚木の密植林に於て割合に枝下の高い所

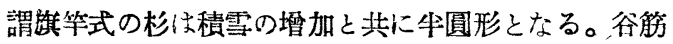
のよく伸長した木は尾根筋の風雪に堪えて成長した木 よりも曲り易い倾向がある。急斜地に在つて主幹の根 際大きく下方上り枝葉の繁つた杉，檜は樹體か谷側に 倾科し尖端附斦か圆弧狀に曲る。かくて幼踰木は梢端 办先に積雪面に接し逐に積雪中に埋没するか，木質柔 軟て彈力性に富むために，著しく曲けられてる特に良 く伸長した稍端部の外挫折したり，割裂したり゙するこ とは珍らしいか，灶老鉧木になると樹冠皘雪の荷雨分

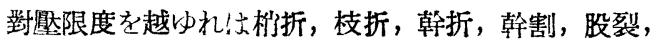
根倒れを生したりする。竹休に於ては曲り竹, 挫折 竹, 割裂竹を生ずる。

7 ) 樹冠皘雪と林木の雾害 林木の雪害の中て 最も廣範園に亘るものは樹冠積雪によるものでる。

\begin{tabular}{|c|c|c|c|c|c|c|c|}
\hline \multicolumn{8}{|c|}{ 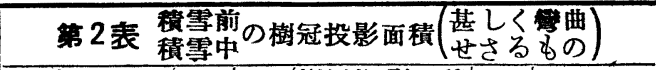 } \\
\hline 測定 & $\begin{array}{l}\text { 測 定 } \\
\text { 年月日 }\end{array}$ & 樹種 & 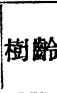 & \multicolumn{2}{|c|}{ 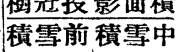 } & $\mid \begin{array}{c}\text { 割合 } \\
\%\end{array}$ & 備 考 \\
\hline 1 & 17. I. 15 & 5 すき & 6 & 1.64 & 0.87 & 53 & \\
\hline 2 & 17. II. 12 & まか & 10 & 3.73 & 2.70 & 72 & \\
\hline 3 & 17. II. 13 & II & 13 & 3.00 & 2.27 & 76 & 垂下中 \\
\hline 4 & "I & すき & 10 & 1.95 & 1.83 & 94 & \\
\hline 5 & "I & "I & 35 & 8.25 & 5.72 & 69 & $\begin{array}{l}\text { 彎曲セズ } \\
\text { 垂下中 }\end{array}$ \\
\hline 6 & " & "I & 15 & 3.23 & 2.50 & 77 & $\begin{array}{l}\text { 彎曲セス } \\
\text { 垂下中 }\end{array}$ \\
\hline 7 & " & "I & 10 & 1.70 & 1.42 & $84^{-}$ & $\begin{array}{l}\text { 彎曲中 } \\
\text { 垂下中 }\end{array}$ \\
\hline 8 & "I & "I & 11 & 2.15 & 1.70 & 79 & $\begin{array}{l}\text { 彎曲セス } \\
\text { 垂下甚ン }\end{array}$ \\
\hline 9 & " & "I & 12 & 2.98 & 1.80 & 60 & $\begin{array}{l}\text { 彎曲セズ } \\
\text { 重下甚 }\end{array}$ \\
\hline 10 & 17. II. 16 & "I & 10 & 2.57 & $2.0 \mathrm{C}$ & 78 & $\begin{array}{l}\text { 僅二学算曲 } \\
\text { 垂下甚 }\end{array}$ \\
\hline 11 & "I & "I & 12 & 1.75 & 1.42 & 81 & $\begin{array}{l}\text { 彎曲中 } \\
\text { 垂甚 }\end{array}$ \\
\hline 12 & 18. II. 19 & "I & 13 & 2.92 & 262 & 90 & \\
\hline 13 & II & " & 22 & 6.97 & 6.96 & 100 & \\
\hline 14 & II & " & 12 & 3.65 & 356 & 98 & \\
\hline 15 & " & "I & 12 & 2.65 & 125 & 47 & $\begin{array}{l}\text { 彎曲セズ } \\
\text { 垂下甚シ }\end{array}$ \\
\hline 16 & "I & $\begin{array}{l}\text { ひの } \\
\text { き }\end{array}$ & 20 & 5.95 & 4.22 & 61 & 垂下中 \\
\hline F均 & & & & & & $i 7$ & \\
\hline
\end{tabular}

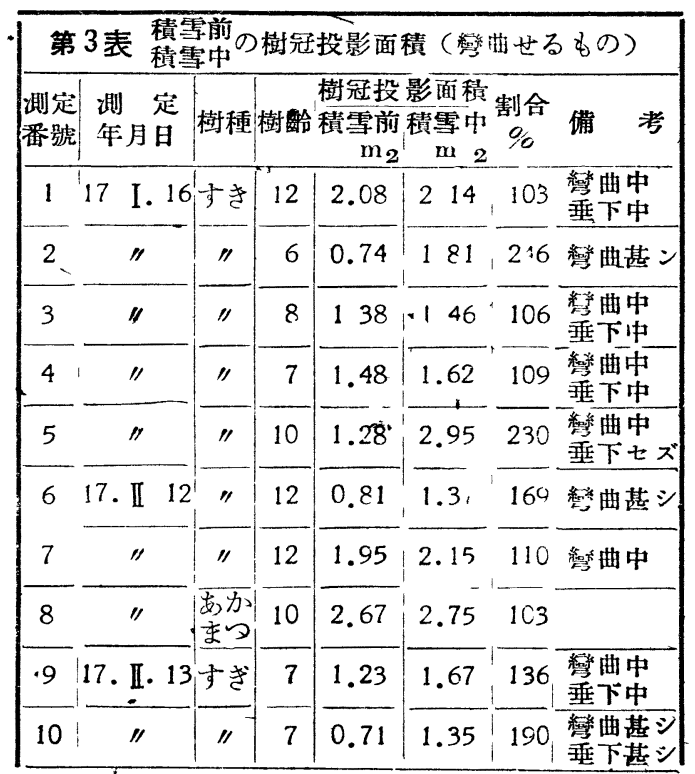




\begin{tabular}{|c|c|c|c|c|c|c|c|}
\hline 11 & 17. II. 12 & すぎ| & 9 & 1.18 & 1.50 & 136 & 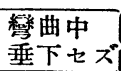 \\
\hline 12 & $"$ & "I & 8 & 1.15 & 1.23 & 107 & \\
\hline 13 & II & \multirow[b]{2}{*}{ " } & 8 & 1.25 & 1.50 & 120 & \multirow{4}{*}{ 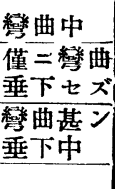 } \\
\hline 14 & 17. II. 16 & & 8 & 0.95 & 1.00 & 105 & \\
\hline 15 & "I & & 10 & 1.90 & 2.30 & 121 & \\
\hline 本均 & & 1 & & & & 139 & \\
\hline
\end{tabular}

密度の小な雪は樹冠に $20 \mathrm{~cm}$ 內外積雪しても重量か輕 く，時間の經過と共に自然落下や融雪のため滑失して 雪害木を生ずることはないか, 粘着性の大な密度の 0.1 以上の雪か短時間に急に $20 \mathrm{~cm}$ 以上ひ降り積ると， 抵抗性の弱い木や竹 は雪害を"蒙るに到 る。從來竹木下雪害 を起した雪は無風の 時に氣温汃 $-20^{\circ} \sim$ $+2.0^{\circ}$ 前後の 比較 的高い折に降つた雪 で, 新積雪の密度が $0.1-0.2$ 位の車い 俗に綿雪、活たえ雪， 水雪などと言はれて 牤る大形の湜潤な粘 着性に富み幹や枝葉 に附着し易く見る間 に總てのものか綿帽 子を被り電腺に子圆 く附着する樣な雪て 積雪量が $2 \mathrm{Ccm}$ 以上 あつ大場合である。 文前日來樹冠に積つ た雪がそのま〉夜中 に谏結し，更に臀日 も粘性に富んな濕り

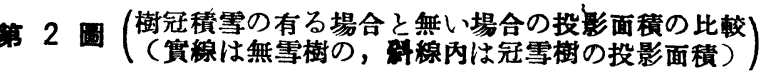

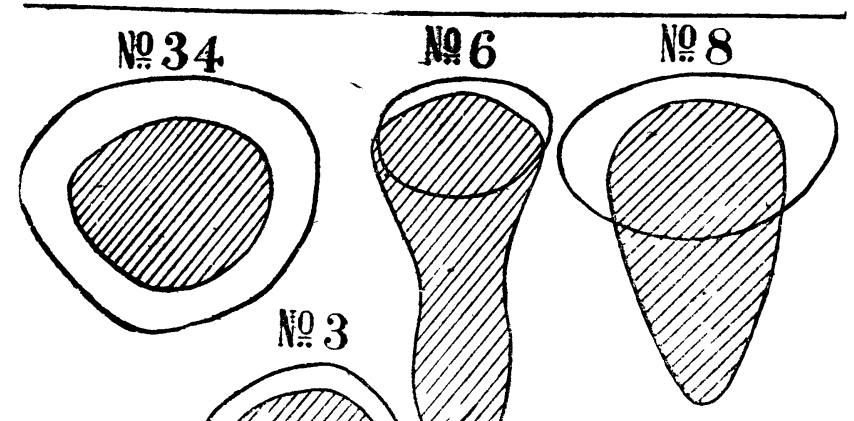
て樹冠の面皘を堽大し逐に雪面に接し，更に皘れ时 中に埋るに到るか，埋る前に新降霄量の $30-40 \%$ の 雪か積り得る。

（2）訝莃の杉に於ては降雪量が多くなれは，樹冠投 影面積は積雪前の 20 ３0\% 位を減するが 50\% 以上 になることは稀てある。又その積雪率は幼路令木より多 少減ずるもの〉如く 25-35\% 位である。

（3）樹冠積雪量は枝數の多少よりも樹形の狀態，樹。 枝葉の繁茂の狀熊に影響されることが多い。

（4）樹の生育狀態及所在場所によつて樹冠積雪量は 異るが，直立木に於ては平地積雪量の $13-50 \%$ か樹 冠に皘乃ものと看做 してよい。樹冠の表 面債に對しては6 一 $20 \%$ で本均は約 10 \%に過ぎない。

(5) 樹冠積雪量は 降雪直後が最大てあ つて, 時間の絓過す ると從つて風其の他 の外力並に枝幹の反 撥力によつて落雪が 始まり荷重を減す る。

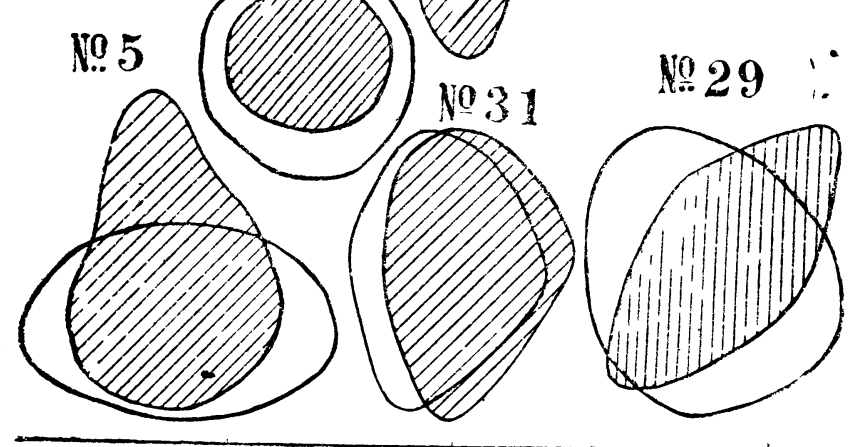

(6) 一旦融解したー 雪计が温度の低下に よつて枝落に湅着す ると容易に葉ち難く なり，その上に更に 新雪が降ると樹冠の 積雪は增大して雪害 を被ることがある。

(万) 平地林に於て は伸長量の大なる杉 は樹冠の積雪によつ て先端部が早く曲げられ，倾斜地の植林に於ては倾斜 の急なる程積雪の荷重により早く幹が曲り，そのため 樹上の積雪量を錯し雪害の原因となる。

(8) 前年に伸長した一年生の梢部分は柔耿なために 曲り易く, 附着積雪量多き時はその前年に伸長よた箇 所との境目より急に曲げられ，時には腰折することが ある。

(9）樹冠積雪によつて，投影の形は幼路木は彎曲し

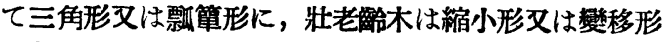
となる。

（1）澍冠に積る雪の量は幼瑹の杉に就ては，降雪量 